\title{
The Effect of Using of Instructional Technology to Elementary School Students' Academic Achievement: A Meta-Analysis Study
}

\author{
Mehmet Fatih AYAZ \\ Hanifi ŞEKERCI \\ Behçet ORAL \\ Dicle University, Ziya Gökalp Faculty of Education
}

\begin{abstract}
:
At this study using of technology in education in the primary school students a metaanalysis is conducted to determine the effects on academic achievement. For that, literature searching related to studies conducted in Turkey is realized. The studies included into research are formed from master and doctoral theses, published or not published articles in refereed scientific journals between 2005-2013 in Turkey as "Instructional Technologies" and own research problems and needed statistical data. There are 19 studies including the sample about instructional technology on the academic achievements of the students in primary schools. Meta-analysis results of the using of technology in teaching, primary school students were found to be positive effect on academic achievement. The study of the average effect size was determined $E S=0.973(95 \% \mathrm{Cl}, S E=0.132)$ with a very close level to strong level by using random effect model. Effects related to the lessons, application time, study type and class level from the operating characteristics were determined. As a result of analysis done by the intermediate variables the highest effect sizes have been observed for social sciences (ES=1,475), in "20 and over" teaching hours, at doctoral theses, and at second class $(E S=1,434)$. According to the obtained results, some recommendations were made for practitioners, program developers and researchers. It is provided that more space to instructional technology in primary school curriculum should be given.

Keywords Instructional Technology, Academic Achievement, Elementary School, Meta-Analysis.

İnönü University

Vol 17, No 1, 2016

pp. $35-54$

DOI: $10.17679 /$ iuefd. 17131503
\end{abstract}

Journal of the Faculty of Education

\section{Suggested Citation}

Ayaz, M. F., Şekerci, H., \& Oral, B. (2016). The effect of using of ınstructional technology to elementary school students' academic achievement: A meta-analysis study, The Inonu University Journal of the Faculty of Education, 17(1), 35-54. DOI: 10.17679/iuefd.17131503 


\section{EXTENDED ABSTRACT}

\section{Introduction}

In today's rapidly evolving and changing world, individuals should look for ways to access information and should apply the information to solve the encountered problems, instead of memorizing and receiving information from a single source (Birişçi \& Metin, 2009). Therefore, the use of teaching materials for educational activities and renewing these materials by supporting technology aspects is a necessity to educate people in the information age. Today, the number of scientific studies is rapidly increasing. It is possible to reach different results in various studies having made about a specific issue. Although, studies design to make comprehensive generalizations, due to the limitations of the studies, it is not always possible to give comprehensive descriptions.

\section{Purpose}

There are numerous studies to identify the relation between instructional strategies use, which is prevalent in almost all teaching areas, and the academic achievement of primary school students (Akamca Özyılmaz, 2008; Baba, 2012; Babur, 2010; Erdağ, 2011; İzgi, 2012; Turan, 2012). In this context, it is gaining importance to answer the question of "how does instructional technology use effects the academic achievements of primary school students" by using meta-analysis method. Therefore, meta-analysis of prospective studies has been made in the literature.

\section{Method}

In order to determine the effect of the use of educational technology to the academic achievement of primary school students, meta-analysis method was used. Meta-analysis is a statistical procedure used for the synthesis of application and interpretation of individual studies. Studies will be included in research, consist of published and unpublished the master's and doctoral theses about "Educational Technologies" in Turkey between the years of 2005-2013 which have with the necessary statistical data about problems of the research and articles published in scientific journals. As a result of the literature review, 19 studies were combined with meta-analysis method. The reliability of the coding in the meta-analysis is an important point. Therefore, all study should be evaluated by at least two experts. By comparing the first and second researchers' analyses, the number of overlapping and nonoverlapping coding was determined. The reliability of coding was found $94 \%$ by using confidence level formula. In this meta-analysis study, the use of educational technologies and the effects of traditional learning methods were compared. In the study, teaching technologies are taken as independent variables, the effect size of the academic achievement of primary school students were taken as the dependent variable. In the analysis of data, CMA, MetaWin, and Excel programs were used.

\section{Findings}

In order to calculate the effect size of the study, first of all, the meta-analysis method to be used should be determined. Firstly, the fixed effect model (SEM) and a random effect model (REM) are required for testing the homogeneity of the study. From $\chi^{2}$ table, with the $95 \%$ significance level, with 18 degrees of freedom, critical value was found to be 28.869 . When homogeneity value of study has been included in the survey calculated according to the fixed effect model was found to be $Q=85.809$ while the random effect model was found to be $Q=28.301$. It is seen that homogeneity of the values found by the random effect model didn't exceed the critical value. Therefore, according to the random effect model, the effect size value is determined to be in homogeneity.

As a result of the analysis made by the random effect model, the mean effect size value was found to be 0.973 with standard error of 0.132 . In the $95 \%$ confidence interval, the lower limit of the effect size was calculated to be 0.715 , the upper limit is calculated to be 1.231 . The positive average effect size value $(+0.973)$ shows that process influence is in favor of the experimental group. Therefore, the use of instructional technology positively impact the academic achievement of primary school students said to be more effective than traditional teaching methods. 


\section{Discussion \& Conclusion}

In total, 19 studies related to the use of instructional technology and its impact on primary school students' academic achievement were combined. The total number of samples in the study (experimental group and control group) is establised by 1260 people. Namely experimental studies involving a total of 1260 sample were combined into a single operation by the meta-analysis method. The overall effect size value of the study according to the random effect model was found to be $\mathrm{ES}=0,973$ (\%95 Cl, SE=0,132).

According to the results, it is more effective to use instructional technologies to increase academic achievements of the primary school students in the lessons of social sciences and science, in third and fourth classes, in doctoral theses and in "20 and over" teaching hours.

According to the results, it is less effective to use instructional technologies to increase academic achievements of the primary school students in the lessons of computer, mathematics, Turkish; in second and fifth classes, in articles and in teaching hours between " 0 and 19 ".

With the results and the experiment in study process in research, these recommendations are made for practitioners, program developers and researchers:

- As a result of the meta-analysis study to determine the impact on the academic success of the use of instructional technologies in primary school students, compared to traditional learning methods, it was determined that instructional technologies have a positive impact in an intermediate level on the achievements of primary school students. Primary school teachers can use instructional technology for effective learning.

- According to the study of the application period, no significant difference was found about the impact sizes on the academic success of the use of instructional technologies in primary school students. However, due to the high impact size output levels in the "20 and over" teaching hours, it can be said that instructional technologies should be used in a time period that get the primary school students comprehend and understand the issues.

- In education programmes, especially in the lessons that increase academic achievement of primary school students, it can be provided that giving wide coverage to instructional technologies and have these technologies used.

- When activities about instructional technologies in the curriculum and textbooks planned, arranging the duration to make the students efficient will increase the functionality.

- When examining the studies with different impact size levels, it can be tried to determine that what kind of factors impact these differences. 


\title{
Öğretim Teknolojileri Kullanımının illkokul Öğrencilerinin Akademik Başarılarına Etkisi: Bir Meta-Analiz Çalışması
}

\author{
Mehmet Fatih AYAZ \\ Hanifi ŞEKERCi \\ Behçet ORAL \\ Dicle Üniversitesi, Ziya Gökalp Eğitim Fakültesi
}

\begin{abstract}
Öz
Bu araştırmada eğitimde teknoloji kullanımının ilkokul öğrencilerinin akademik başarılarına etkisini belirlemek amacıyla bir meta-analiz çalışması yapılmıştır. Bunun için Türkiye'de yapılmış çalışmalarla ilgili literatür taraması yapılmıştır. Araştırmaya dâhil edilecek çalışmalar, 2005-2013 yılları arasında Türkiye'de "Öğretim Teknolojileri" ile ilgili yayımlanmış ve yayımlanmamış, araştırma problemine ve gerekli istatistiksel verilere sahip olan yüksek lisans ve doktora tezleri ile hakemli bilimsel dergilerde yayınlanmış makalelerden oluşmaktadır. Literatür taraması sonucunda öğretim teknolojilerinin kullanımının ilkokul ögrencilerinin akademik başarılarına etkisine ilişkin toplam 19 çalışma meta-analize dâhil edilmiştir. Metaanaliz sonucunda ögrretim teknolojilerinin kullanımının, ilkokul öğrencilerinin akademik başarılarına pozitif etkisi olduğu belirlenmiştir. Çalışmaların ortalama etki büyüklügünün, rastgele etkiler modeline göre $E S=0,973$ (\%95 Cl, SE=0,132) ile güçlü düzeye çok yakın bir seviyede olduğu belirlenmiştir. Çalışma karakteristiklerinden dersler, uygulama süresi, çalışma türü ve sınıf düzeyi ile ilgili etki büyüklügü farkları belirlenmiştir. Yapılan ara değişken analizleri sonucunda en yüksek etki büyüklügü değerlerinin sosyal bilgiler dersinde $(E S=1,475), 20$ saat ve üzeri ders saatinde $(E S=1,133)$, doktora tezlerinde $(E S=1,257)$ ve ikinci sinıf düzeyinde $(E S=1,434)$ görülmüştür. Elde edilen sonuçlara göre uygulayıcı, program geliştirici ve araştırmacılara yönelik önerilerde bulunulmuştur. Öğretim teknolojilerinin ilkokul programlarında daha fazla yer verilmesi sağlanabilir.
\end{abstract}

Anahtar Kelimeler: Öğretim Teknolojileri, Akademik Başarı, ilkokul, Meta-analiz.

\section{Önerilen Atıf}

Ayaz, M. F., Şekerci, H., \& Oral, B. (2016). Öğretim teknolojileri kullanımının ilkokul öğrencilerinin akademik başarılarına
İnönü Üniversitesi Eğitim Fakültesi Dergisi Cilt 17, Sayı 1, 2016 ss. $35-54$

DOI: $10.17679 /$ iuefd. 17131503 $\begin{array}{lr}\text { Gönderim Tarihi : } 15.07 .2015 \\ \text { 1. Düzeltme } & : 01.12 .2015 \\ \text { 2. Düzeltme } & : 15.01 .2016 \\ \text { Kabul Tarihi } & : 21.03 .2016\end{array}$

\footnotetext{
etkisi: Bir meta-analiz çalışması. Inönü Üniversitesi Eğitim Fakültesi Dergisi, 17(1), 35-54. DOI: 10.17679/iuefd.17131503
} C $10.17679 /$ unefd. 17131503 


\section{Giriş}

Sanayi devrimi ile devletler gücünü üretime dayandırırken, günümüzde bu güç bilgiye dayanmaktadır. Bilgi çağını yaşayan insanlık sürekli bir değişim-gelişim içindedir (Özdemir, 2006). 21. yüzyılın insanoğlu için ortaya koyduğu gereksinimler, her geçen gün gelişen bilim ve teknolojiyle birlikte artmakta ve değişmektedir. Bu değişimin bir yönü teknolojideki değişimdir (Ünal, 2012). Bilgi toplumuna dönüşüm süreci tüm toplumların ve kurumların dönüşümüne neden olmuş bu değişimden eğitim kurumları da payını almışır. Bu anlamda eğitim kurumları teknolojiyi yaygın olarak kullanmakta ve eğitim ve öğretim faaliyetlerini yetkin kılmaya çalışmaktadır (Çam Aktaş, 2014: 188). Günümüzün hızla gelişen ve değişen dünyasında bireyler, bilgiyi mevcut tek bir kaynaktan alıp ezberlemek yerine bilgiye ulaşma yollarını arayan, ulaştığı bilgileri karşılaştığı problemlerin çözümüne uygulayabilen nitelikte olmalıdır (Biriş̧̧i ve Metin, 2009). Bunun için eğitim öğretim etkinlikleri için öğretim materyallerinin kullanılması ve bu materyallerin teknoloji yönü ile desteklenmesi ve yenilenmesi bilgi çağı insanı yetiştirme adına zorunluluktur. Çünkü öğretim materyallerinin öğrencilerin bireysel farklılıklarına, öğrenme stillerine ve stratejilerine uygun olması öğrencilerin yaparak yaşayarak, aktif bir şekilde iletişim kurarak öğrenmelerine yardımcı olur (Fer, 2011: 25). Bu anlamda eğitim öğretim etkinliklerinde teknolojilerinin kullanımı eğitim programlarında yer almış ve bunları etkili kullanımı ile ilgili çalışmalar ve tartışmalar yoğun bir şekilde yapılmıştır (Akamca Özyılmaz, 2008; Baba, 2012; Babur, 2010; Erdağ, 2011; İzgi, 2012; Turan, 2012). Hızla gelişen bilişim ve iletişim teknolojisi okullardaki görsel ve işitsel öğretim alternatiflerini artırmakta aynı zamanda da bu yönde öğretim programlarında değişikliklerin yapılmasını zorunlu kılmaktadır (Akın, 2007).

Eğitim-öğretim etkinliklerinde teknolojik araçlardan yararlanılması eğitim ve öğretim teknolojileri kavramlarının tanımına ilişkin tartışmaları da başlatmışır. "Eğitim teknolojisi, öğrenme-öğretme ortamlarını etkili bir şekilde tasarımlayan, öğrenme ve öğretme de meydana gelen sorunları çözen, öğrenme ürününün kalitesini ve kalıııı̆̆ını artıran bir akademik sistemler bütünü olarak ifade edilirken" (İşman, 2002), "öğretim teknolojileri de eğitim teknolojisinin bir alt kümesi olarak değerlendirilmiştir ve özel olarak bir disiplin alanına ilişkin hedeflere ulaşmak için çeşitli materyallerin kullanımı olarak tanımlanmışır" (Ayaydın, 2014). Bu materyallerin öğrenme ortamlarında kullanılmasının öğretimin niteliğini arttırdığına yönelik görüşlerin de yaygınlaşmasına neden olmuştur.

Öğrenme ortamlarının öğrenciler tarafından istenilen ve aranılan ortamlar olarak zenginleştirilmesi için teknolojinin eğitimde kullanımı gerekmektedir (Tosun, 2006). Çünkü eğitim kalitesinin artııımasında araç ve gereç kullanımı ve bunların çağın teknolojisine uygun olmaları eğitim hizmetlerinin verimliliğini etkileyen önemli etmenlerdir (Sağlıker, 2009). Eğitimde teknoloji kullanımı dendiğinde akla ilk gelen bilgisayar ve bilgisayar yardımı ile kullanılan akılı tahta, projeksiyon cihazı vb.dir. Bilgisayarların uzunca süredir öğretme ve öğrenme aracı olarak okullarda kullanıldığı söylenebilir (Akçayır, 2011). Bilgisayarlar eğitim ortamında öğretim tasarımında kullanımı ile öğrenme ortamı zenginleştirilmektedir. Bilgisayarlar vasıtasıyla benzetişimler, özel öğreticiler, alıştırmalar, oyunlar, eğitsel slaytlar vs. öğrencilerin öğretim etkinliklerinden daha fazla verim almalarına olanak sağlamaktadır (Şimşek, 2011). Ancak sadece bilgisayarlarının ve türevlerinin öğretim teknolojileri kapsadığı söylenemez. Derse, konu alanına, öğrenen ve öğretenlerin özelliklerine göre kullanılan öğretim teknolojileri değişik gösterebilir ve göstermektedir. Karikatürler, görselişitsel materyaller vb. ürünler öğretim teknolojileri içine girmektedir. Öğretim araçlarının zenginleştirilmesi ile öğrenme ortamları farklı kişisel özellikler gösteren öğrenciler için zevkli ve eğlenceli hale gelirken öğrenme oranı da yükseltilebilir, eğitim öğretimin etkililiği arttıılabilir (Keser ve Çakır, 2009). Öğretim teknolojilerini uzmanlar farkı şekillerde tanımlamışlardır (Alkan, 2011; Fer, 2011; Ocak, 2011; Uşun, 2006). Bu tanımların bütünleştirilmesi ile öğretim teknolojileri şu şekilde tanımlanabilir: "Belirlenmiş hedefler çerçevesinde, daha etkili bir öğrenme-öğretme süreci için öğrenme-öğretme kuramlarının en etkin şekilde uygulamaya dönüştürülmesidir. Bunun için öğrenme-öğretme süreçlerinin tasarlandığı, geliştirildiği, çeşitli türdeki materyallerin işe koşularak uygulandığı ve son olarak öğrenme-öğretme etkinliklerinin değerlendirildiği bir süreçtir." Bu noktada öğretim teknolojilerinden beklentiler eğitimde verimi ve etkililiği yükseltmek, eğitim uygulamalarında bilimsel ve rasyonel bir temel oluşturmak, öğrenmeyi hızlandırmak, fırsat eşitliğini yaygınlaştırmak, öğretimi kitlelere yaymak ve bireyselleştirmektir (Uşun, 2006: 4). Eğitimde teknoloji destekli materyaller kullanılarak öğrencilerin kendi hızlarına göre öğrenebilmelerine imkân sağlanır, öğrenciler için sıkııı gelebilecek konuların ilginç ve eğlenceli hale getirebilir, öğretmenler ders sırasında zamanı etkili ve verimli kullanabilir (Şen, 2013).

Ülkemizde eğitim-öğretim faaliyetlerini daha nitelikli hale getirmek amacıyla teknolojik materyallerden yararlanma konusunda büyük maliyetli projeler hayata geçirilmiştir. Bu projelerin en geniş kapsamlısı ise 
FATIH Projesidir. Bu proje ile okul öncesi, ilkokul, orta okul ve orta öğretim düzeyindeki okulların 620.000 dersliği bilgisayar, akıllı tahta ve projeksiyon cihazı ile donatılmıştır (Gürol, Donmuş ve Arslan, 2012). Bunun yanında eğitimde teknolojik materyallerden yararlanma ile ilgili yapılmış birçok akademik çalışmaların varlığından da söz edilebilir. Yapılan çalışmaların her okul kademesinde ve çeşitli derslerde yapıldığı da görülmektedir. Örneğin Akkaya (2011) bilgisayar destekli görsel materyaller olan karikatürlerin dil bilgisi öğretiminde etkililiğini incelemiş ve akademik başarıya olan olumlu etkisini ortaya koymuştur. Öztürk (2014) Fen öğretiminde bilgisayar destekli öğretim uygulamalarının öğrencilerin akademik başarılarını, bilimsel düşünme becerilerini ve kavramsal anlama düzeylerinin gelişiminde etkili olduğunu gözlemlemiştir. Orta öğretim düzeyinde eğitimde teknoloji kullanımına ilişkin yapılan çalışmalara bakıldığında Şenlen (2015) Biyoloji öğretiminde bilgisayar destekli öğretimin öğrenci başarısına olumlu etkisini ortaya koymuşken, Bayturan (2011) orta öğretim matematik öğretiminde bilgisayar destekli öğretimin geleneksel öğretime göre öğrencilerin akademik başarısını olumlu yönde etkilediğini belirtmiştir. Yükseköğretim düzeyinde ise Illyasoğlu (2012) Genel Fizik I dersinde yapılan bilgisayar destekli fen öğretiminin geleneksel öğretime göre öğretmen adaylarının akademik başarısını olumlu yönde etkilediği sonucuna ulaşmıştır.

Sürekli artan bilimsel çalışmalarla birlikte çok farklı sonuçlara ulaşılabilmektedir. Bilimin, elde edilen bilgilerin derlenip değerlendirilmesi olduğu düşünüldüğünde literatürdeki bilgilerin sentezlenmesinin önemli olacağı görülmektedir. Bu nedenle geçerlik ve güvenirlik düzeyi diğer literatür tarama yöntemlerine göre daha sağlıklı belirlenebilen, objektiflik düzeyi daha yüksek olan meta-analiz yönteminin birincil çalışmaları birleştirmek için daha uygun olacağı görülmektedir (Üstün ve Eryılmaz, 2015).

Öğretim alanlarının tümünde kullanılan öğretim teknolojileri kullanımının özellikle somut işlemler döneminde bulunan öğrencilerde daha fazla kullanıldığı bilinmektedir (Demirel ve Altun, 2012; Sever, 2011; Yanpar Yelken, 2012). Türkiye'de de daha çok ilkokul öğrencilerinin akademik başarılarına etkisini belirlemek amacıyla yapılmış çalışmaların olduğu belirlenmiştir (Akamca Özyılmaz, 2008; Baba, 2012; Babur, 2010; Erdağ, 2011; İzgi, 2012; Turan, 2012). Bu bağlamda, "Öğretim teknolojileri kullanımının, ilkokul öğrencilerinin akademik başarılarına etkisi ne düzeydedir?" sorusuna meta-analiz yöntemiyle cevap bulmanın önemli olduğu düşünülmektedir. Araştırmada öğretim teknolojileri kullanımını etkileyebileceği düşünülen ve verilerin kodlanması sonucu netleşen çeşitli ara değişkenler (dersler, sınıf düzeyi, yayın türleri, uygulama süresi ve örneklem büyüklüğü) belirlenmiştir. Bu amaçla aşağıdaki sorulara yanıt aranmıştır:

1. Öğretim teknolojileri kullanımı, ilkokul öğrencilerinin akademik başarıları üzerine etkisi ne düzeydedir?

2. Öğretim teknolojileri ile ilgili yayınların etki büyüklükleri arasında, ilkokul öğrencilerinin farklı derslerdeki (Bilgisayar, Fen Bilgisi, Hayat Bilgisi, İngilizce, Matematik, Sosyal Bilgiler, Türkçe) akademik başarılarında anlamlı bir farklılık var mıdır?

3. Öğretim teknolojileri ile ilgili yayınların etki büyüklükleri arasında, ilkokul öğrencilerinin akademik başarılarında sınıf düzeylerine (1., 2., 3., 4. ve 5. Sınıf) göre anlamlı bir farklılık var mıdır?

4. Öğretim teknolojileri ile ilgili yayınların etki büyüklükleri arasında, ilkokul öğrencilerinin akademik başarılarında yayın türlerine (Doktora tezi, yüksek lisans tezi ve makale) göre anlamlı bir farklılık var mıdır?

5. Öğretim teknolojileri ile ilgili yayınların etki büyüklükleri arasında, çalışmalardaki uygulama süresine (0-19 saat, 20 ve üstü saat) göre ilkokul öğrencilerinin akademik başarılarında anlamlı bir farklıık var mıdır?

6. Öğretim teknolojileri ile ilgili yayınların etki büyüklükleri arasında, çalışmalardaki örneklem büyüklüğüne göre (1-29 kişi, 30 ve üstü kişi) göre ilkokul öğrencilerinin akademik başarılarında anlamlı bir farklılık var mıdır?

\section{YÖNTEM}

\section{Araştırma Modeli}

Araştırmada meta-analiz yöntemi kullanılmıştır. "Meta-analiz, birincil çalışmaların sentezlenmesi ve yorumlanması amacıyla kullanılan istatistiksel prosedürler uygulamasıdır" (Cohen, Manion ve Morrison, 2007). Meta-analiz, bir alanda benzer çalışmalardan elde edilen sonuçların birleştirilmesi için kullanılan istatistiksel bir yöntemdir (Ergene, 1999). Meta-analiz, birincil çalışmalardan elde edilmiş deneysel bulguların birleştirilmesini sağlamak için kullanılan istatistiksel analizlerden oluşan bir yöntemdir (Glass, 1976).

Bir meta-analiz çalışmasının niteliğinin arttırılması için mutlaka izlenmesi gerekli olan aşamalar belirlenmelidir (Ayaz, 2015). Bu çalışmada DeCoster'ın (2004) önerdiği altı işlem basamağından oluşan aşamalar izlenmiştir. Bunlar:

1. Araştırma probleminin belirlenmesi, 
2. Literatürün taranması ve verilerin toplanması,

3. Çalışmaların kodlanması,

4. Etki büyüklüğü indeksinin bulunması,

5. İstatistiksel analizin yapılması,

6. Bulguların yorumlanması ve raporlaştırma.

\section{Verilerin Toplanmast}

Araştırmaya dâhil edilecek çalışmalar, taramalar sonucunda 2014 yılına ait herhangi bir çalışma bulunamadığından 2005-2013 yılları arasında Türkiye'de "Öğretim Teknolojileri" ile ilgili yayımlanmış ve yayımlanmamış, araştırma problemine ve gerekli istatistiksel verilere sahip olan yüksek lisans ve doktora tezleri ile bilimsel dergilerde yayımlanmış makalelerden oluşmaktadır. Çalışmalar tam metin olarak incelenmiştir.

Türkiye'de yapılan lisansüstü tezlerin taraması hem Türkçe hem de İngilizce olarak YÖK Ulusal Tez Merkezi internet sitesinden 15.10.2014 ve 23.10.2014 tarihleri arasında gerçekleştirildi. Taramada, başlığında ve anahtar kelimelerinde Türkçe ve İngilizce olarak içinde "bilgisayar destekli", "karikatür" ve "materyal" kelimeleri olan tezler listelenmiştir. Listeleme sonucunda araştırma sınırları içerisinde kalan 812 adet tez ismine ulaşılmıştır. İncelemeler özetler üzerinden yapılmıştır. İncelemeler sonucunda araştırma problemine ve dâhil edilme ölçütlerine uygun tezler çalışmaya dâhil edilmiştir. Kısıtlamalı olan 6 tez ve tez merkezinde bulunmayan 3 tezin yazıldığı üniversitenin kütüphanesi veya yazarları ile iletişime geçilip istenmiştir. Bu şekilde toplam 3 teze ulaşılmıştır. 2 teze hiçbir şekilde ulaşılamamıştır. İnceleme boyunca öğretim teknolojilerinin ilkokul öğrencilerinin akademik başarılarına etkisine yönelik 16 teze ulaşılmıştır.

Türkiye'de yayınlanan makalelere ulaşmak amacıyla literatür taraması ULAKBIM, ASOS ve hakemli bilimsel dergilerde yapılmıştır. Taramada, başlığında ve anahtar kelimelerinde Türkçe olarak içinde "bilgisayar destekli", "karikatür" ve "materyal", İngilizce olarak "computer assisted", "computer based", "caricature" ve "material" kelimeleri olan tezler listelenmiştir. İncelemeler özetler üzerinden yapılmıştır. Toplam 22 makale ismine ulaşılmıştır. Türkiye'de yüksek lisans ve doktora tezlerinin ayrıca makale olarak yayınlanmasından dolayı makaleler ve tezler karşılıklı olarak taranmıştır. Hem tez hem makale olarak yayımlanan 3 yayının aynı anda çalışmaya dâhil edilmesi engellenmiştir. Yapılan incelemeler sonucunda yapılan öğretim teknolojileri ile ilgili öğrencilerin akademik başarılarına etkisine yönelik 3 makale çalışmaya dâhil edilmiştir.

Literatür taraması sonucunda toplam 19 çalışma meta-analiz yöntemiyle birleştirilmiştir. Veriler toplanırken bir önceki eğitim sistemine göre ilkokul düzeyinde sayılan 5. Sınıflar ile ilgili yapılan çalışmalar da metaanalize dâhil edilmiştir.

\section{Dâhil Edilme Ölçütleri}

Araştırmaya dâhil edilen çalışmalar için kullanılan ölçütler şunlardır:

1. Çalışmanın 2005-2013 yılları arasında Türkiye'de yapılmış ve yayımlanmış veya yayımlanmamış Türkçe veya İngilizce dillerinde yazılmış olması.

2. Çalışmanın yüksek lisans tezi, doktora tezi veya yurtiçi hakemli bilimsel dergilerde yayımlanmış makale olması.

3. Deneysel ve yarı deneysel çalışmalar olması.

4. Deney grubuna öğretim teknolojilerinin, kontrol grubuna ise geleneksel öğretim yaklaşımı uygulanması.

5. Etki büyüklüğünü hesaplanması için yeterli olan değerlerin (aritmetik ortalama, standart sapma, örneklem büyüklüğü) olması.

\section{Verilerin Kodlanması}

Araştırmada çalışmaların meta-analize dâhil edilme ölçütlerine uygun olup olmadığının anlaşılması ve metaanalizde çalışmalar arasında karşılaştırma yapılabilmesi için çalışmanın amacına uygun olarak bir kodlama formu (Ek-2) düzenlenmiştir. Kodlama formunda bulunan özellikler şunlardır: Çalışmanın adı, yazarı, türü, yayınlandığı yıl, çalışmada kullanılan ölçeğin kim tarafından hazırlandığı, uygulama süresi, uygulandığı il, uygulandığı öğrenci grubunun öğrenim düzeyi ve çalışmadaki istatistikî verilerdir.

Meta-analizde kodlamaların güvenirliğini sağlamak için kodlamalar biri Eğitim Bilimleri alanında doktorasını tamamlamış, biri Sınıf Öğretmenliği Eğitimi alanında doktora öğrenimi devam eden iki araştırmacı tarafından yapılmıştır. Birinci ve ikinci araştırmacının analizleri karşılaştırılarak güvenirlik düzeyi (Miles ve Huberman, 2002) \%94 olarak hesaplanmıştır. Bu nedenle kodlamaların güvenilir olduğu söylenebilir. Örtüşmeyen 
kodlamaların, dikkatten kaçan yerler olduğu görülmüş ve iki kodlayıcı tarafından verilen ortak kararla düzeltilmiştir.

\section{Verilerin Analizi ve Yorumlanmast}

Bu çalışmada işlem etkisi meta-analizi yöntemi kullanılmıştır. Bu yöntemde etki büyüklüğü olarak standartlaştırımış aritmetik ortalamalar farkı etki büyüklüğü tercih edilmiştir. Bunun nedeni, dahil edilen çalışmaların tamamında gruplar arasındaki farklılığı test etmek için aynı ölçeğin kullanılmamasıdır (Wolf, 1986; Cohen, 1988; Hunter ve Schmidt, 1990; Rosenthal, 1991; Lipsey ve Wilson, 2001; Huffcutt, 2002; Schulze, 2004).

Etki büyüklükleri yorumlanırken Cohen, Manion ve Morrison'un (2007) sınıflandırması kullanılmıştır. Bu sınıflandırmaya göre;

- $\quad 0 \leq$ Etki büyüklüğü değeri $\leq 0,20$ zayıf,

- $\quad 0,21 \leq$ Etki büyüklüğü değeri $\leq 0,50$ küçük,

- $\quad 0,51 \leq$ Etki büyüklüğü değeri $\leq 1,00$ orta,

- $\quad 1,01 \leq$ Etki büyüklüğü değeri güçlü düzeyde etkisi vardır.

Meta-analizde etki büyüklükleri hesaplanmadan Hedges ve Olkin'in (1985) Q istatistikleri (etki büyüklüklerinin ve evren örneklemlerinin homojenliğini ölçmede kullanılan testler) diye tanımladıkları analiz ile hangi istatistiksel modelin kullanılacağına karar verilir. Sabit etkiler ve rastgele etkiler model olmak üzere iki ayrı model bulunmaktadır.

Sabit etkiler modelinde her çalışmanın aynı etkiye sahip olduğu varsayılır (Borenstein vd., 2009). Rastgele etkiler modeli ise çalışmaların etki büyüklüklerinin ortalamasını tahmin etmektedir (Borenstein vd, 2013: 86). Çalışmaların her birinde çalışmayı etkileyen faktörler büyük ihtimalle farklııı gösterecektir. Bu farklılıkların varlığının önemli olduğu düşünülüyorsa rastgele etkiler modeli kullanmak daha uygundur.

Bu meta-analiz çalışmasında öğretim teknolojilerinin kullanımı ile geleneksel öğrenme yöntemlerinin etkileri karşılaştırımıştır. Çalışmada, öğretim teknolojileri bağımsız değişken, ilkokul öğrencilerinin akademik başarılarının etki büyüklükleri bağımlı değişken olarak alınmıştır. Ara değişken analizlerinde analog ANOVA testi kullanılmıştır. Verilerin analizinde Comprehensive Meta-Analysis 2.0, MetaWin ve Microsoft Office Excel programları kullanılmıştır.

Genel Etki Büyüklüğ̈̈ Bulguları

\section{BULGULAR}

Çalışmaların homojenliğine ve genel etki büyüklüğüne ilişkin bulgular Tablo 1'de verilmiştir. Tablo 1.

Homojenlik ve Genel Etki Büyüklüğ̈̈ ile ilgili Bulgular

\begin{tabular}{|c|c|c|c|c|c|c|c|}
\hline \multirow[b]{2}{*}{ Model } & \multirow{2}{*}{$\begin{array}{l}\text { Ortalama } \\
\text { Etki } \\
\text { Büyükklüğüu } \\
\text { Değeri }\end{array}$} & \multirow[b]{2}{*}{$\begin{array}{c}\text { Serbestlik } \\
\text { Derecesi }\end{array}$} & \multirow[b]{2}{*}{$\begin{array}{c}\text { Homojenlik } \\
\text { Değeri }\end{array}$} & \multirow[b]{2}{*}{$\begin{array}{c}\text { Ki-Kare } \\
\text { Tablo } \\
\text { Değeri }\end{array}$} & \multirow[b]{2}{*}{$\begin{array}{c}\text { Standart } \\
\text { Hata }\end{array}$} & \multicolumn{2}{|c|}{$\begin{array}{c}\text { Etki } \\
\text { Büyüklüğüu } \\
\text { için \%95 } \\
\text { Güven Aralığı }\end{array}$} \\
\hline & & & & & & $\begin{array}{c}\text { Alt } \\
\text { Sinır }\end{array}$ & $\begin{array}{l}\text { Üst } \\
\text { Sınır }\end{array}$ \\
\hline SEM & 0,952 & 18 & 85,809 & 28,869 & 0,059 & 0,837 & 1,067 \\
\hline REM & 0,973 & 18 & 28,301 & 28,869 & 0,132 & 0,715 & 1,231 \\
\hline
\end{tabular}

$\chi^{2}$ tablosundan \%95 anlamlılık düzeyinde on sekiz serbestlik derecesi ile kritik değer 28,869 olarak bulunmuştur. Araştırmaya dâhil edilen çalışmaların homojenlik değeri sabit etkiler modeline göre hesaplandığında $\mathrm{Q}=85,809$, rastgele etkiler modeline göre ise $\mathrm{Q}=28,301$ olarak bulunmuştur. Rastgele etkiler modeline göre bulunan homojenlik değerinin kritik değeri aşmadığı görülmektedir. Bu nedenle çalışmaların etki büyüklüğü değerlerinin rastgele etkiler modeline göre homojen özellikte olduğu belirlenmiştir.

Rastgele etkiler modeline göre yapılan analiz sonucunda ortalama etki büyüklüğü değeri 0,132 standart hata ile 0,973 olarak bulunmuştur. \%95 güven aralığında etki büyüklüğünün alt sınırı 0,715, üst sınırı 1,231 olarak hesaplanmıştır. İstatistiksel anlamlılığa bakıldığında $Z=7,399$ ve $p=0,000$ olarak bulunmuştur. Buna göre ulaşılan sonucun istatistiksel olarak anlamlı olduğu söylenebilir. Yapılan güç analizi sonucunda değer 0,874 
olarak bulunmuştur. Bu yüksek değerdir ve bu çalışmanın gerçek bir etkiyi doğru bir şekilde belirlediği söylenebilir.

Etki büyüklüğü değerinin pozitif çıkması $(+0,973)$, işlem etkisinin deney grubu lehine olduğunu göstermektedir. Bundan dolayı, öğretim teknolojileri kullanımının, ilkokul öğrencilerinin akademik başarılarına etkisinin geleneksel öğretim yöntemlerine göre daha etkili olduğu söylenebilir. Bu etki Cohen ve arkadaşlarının (2007) sınıflandırmasına göre orta düzeyde bir etkidir.

Çalışmaların etki büyüklüğü ile ilgili bulgular Şekil 1'de verilmiştir.

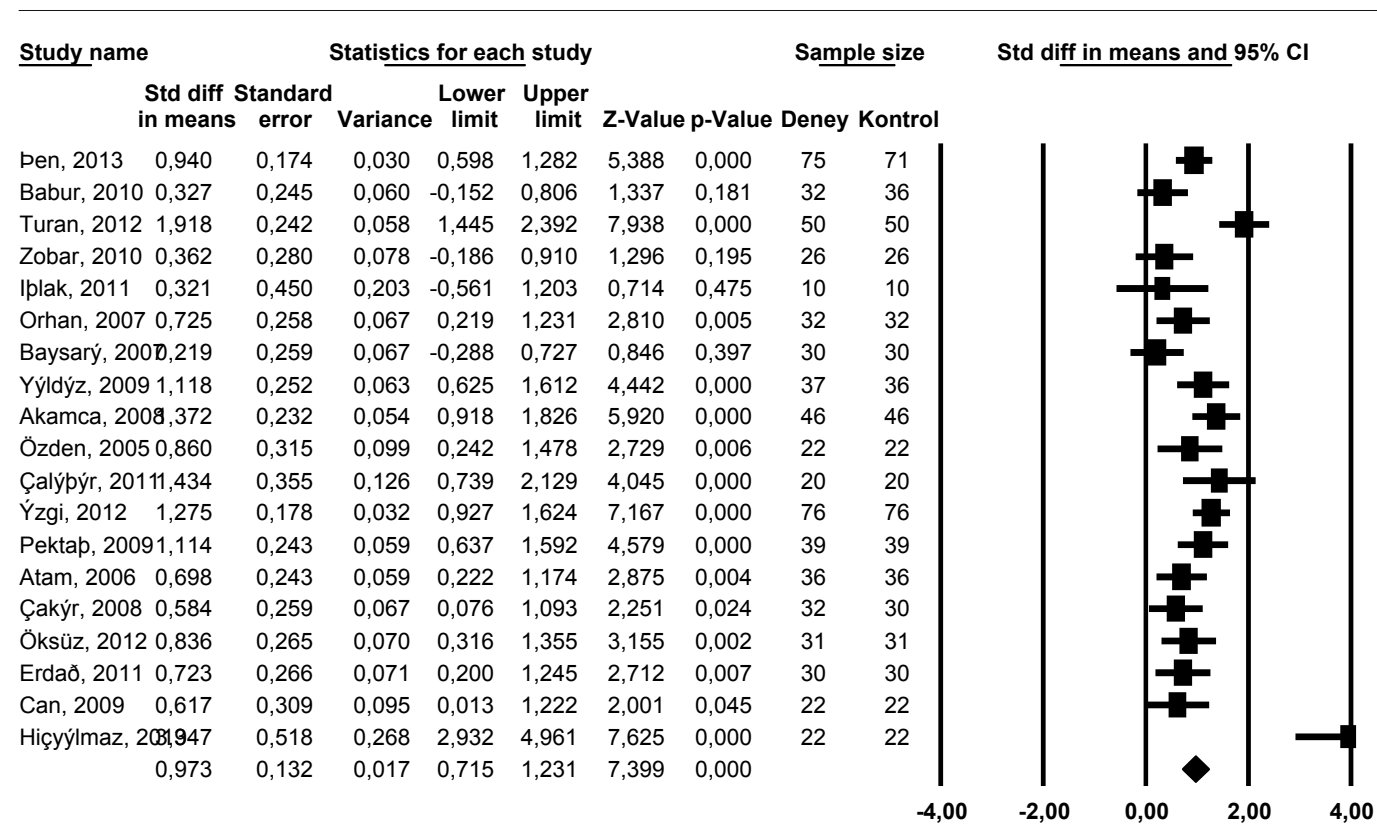

Şekil 1. Çalışmaların Etki Büyüklüğü Değerleri

Çalışmalara ait etki büyüklükleri incelendiğinde en küçük etki büyüklüğü değerinin 0,219, en yüksek etki büyüklüğü değerinin ise 3,947 olduğu belirlenmiştir. Çalışmaların etki büyüklüklerine bakıldığında 19 çalışmanın tamamı öğretim teknolojilerinin uygulandığı deney grubu lehine bir etkiye sahiptir. Araştırmaya dâhil edilen çalışmaların etki büyüklüklerinin normal dağılım grafiği Şekil 2'de verilmiştir.

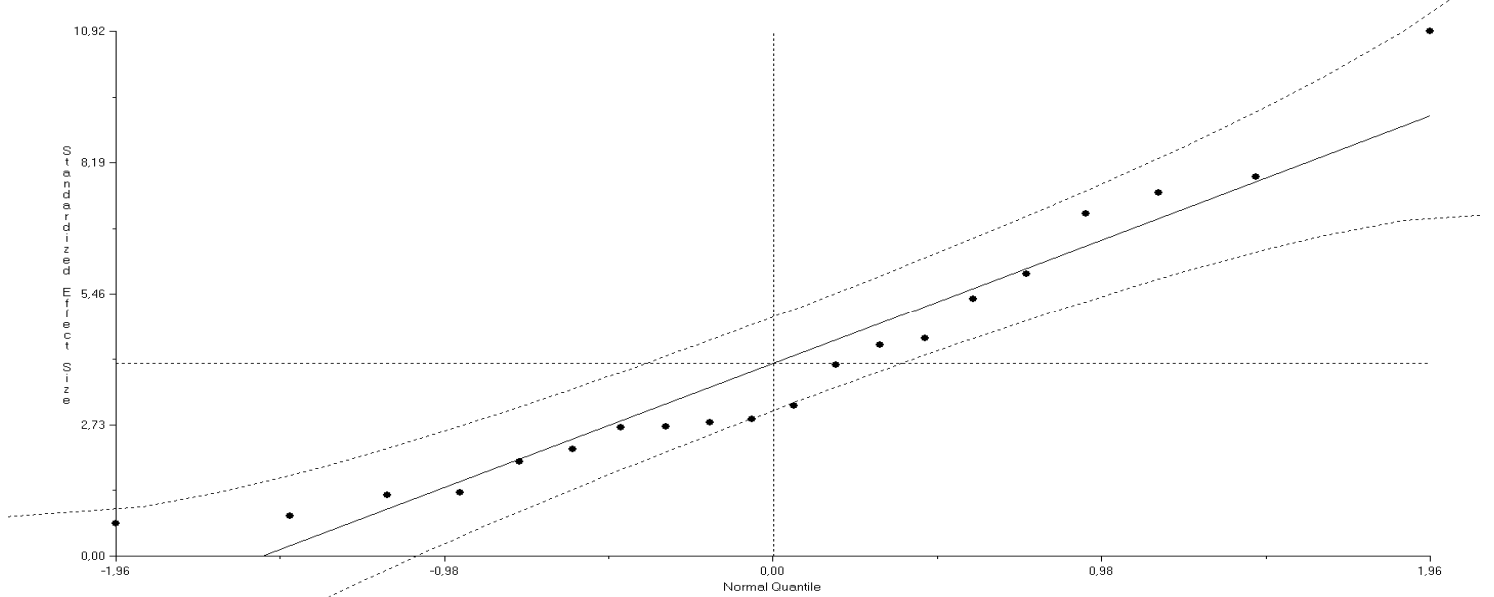

Şekil 2. Etki Büyüklüklerinin Normal Dağılım Grafiği

Çalışmaların etki büyüklüklerinin normal dağılım grafiğine bakıldığında etki büyüklüklerinin normal dağılım doğrusu yakınında oldukları, belirtilen sınırları aşmadığı görülmektedir. Bu nedenle araştırmaya dâhil edilen çalışmaların normal dağılım gösterdiği belirlenmiştir. 
Meta-analize dâhil edilen çalışmaların etki büyüklüklerine ait bulguların anlamlılığının değişmesi için gerekli olan çalışmaların sayısı Orwin Güvenli N yöntemi ile analiz edilmiştir. Orwin Güvenli N yöntemi ile ortalama etki büyüklüğü sıfır olan çalışma sayısı hesaplanır (Hunter ve Schmidt, 1990; Lipsey ve Wilson, 2001). Orwin Güvenli N yöntemi ile bulunan etki büyüklüğü düzeyini Cohen ve arkadaşlarının (2007) etki büyüklüğü sınıflandırmasında bir alt düzeye düşürebilecek etki büyüklüğü sıfır olan çalışma sayısı hesaplanır. Bu bulgu meta-analiz sonucu bulunan etki büyüklüğünün güvenirliği hakkında fikir vermektedir. Öğretim teknolojileri kullanımının, ilkokul öğrencilerin akademik başarılarına etkisine ilişkin genel etki büyüklüğü değeri 0,973 bulunmuştur. 0,973 etki büyüklüğü değerini, 0,01 etki büyüklüğü değerine düşürmek için etki büyüklüğü değeri sıfır olan gerekli çalışma sayısı 1790 olarak bulunmuştur. Bunun yanında yayın yanlılığının olup olmadığı Şekil 3'te verilen Huni Grafiği (Funnel Plot) grafiği yardımıyla da yorumlanabilir.

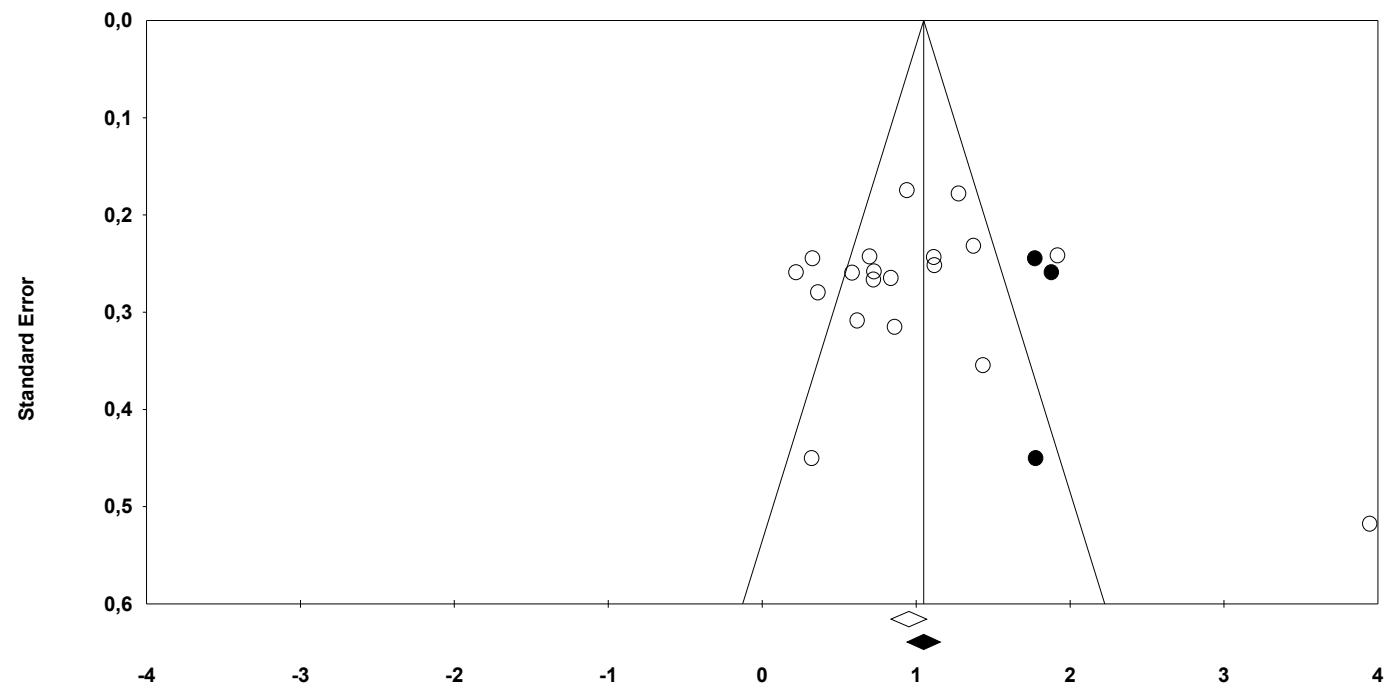

Şekil 3. Etki Büyüklüklerinin Huni Grafiği

Huni grafiğinde yayın yanlılığı olması durumunda etki büyüklükleri asimetrik bir şekilde yer alacaklardır. Yayın yanlılığı olmaması durumda ise simetrik dağılım gösterirler. Ancak Duval ve Tweedie'nin kes ve ekle yöntemiyle oluşturulan huni grafiğinin sağ tarafına üç çalışma eklenmesi durumunda tam olarak simetriklik sağlanacağı görülmektedir. Bu da yayın yanlılığın düşük olduğunu göstermektedir. Düzeltilmiş ortalama etki büyüklüğü değeri 1,084 olarak bulunmuştur.

Çalışmaların Dersler ile ilgili Probleme Ait Bulgular

Etki büyüklüklerinin, derslere göre farklılaşıp farklılaşmadığına ilişkin bulgular Tablo 2'de verilmiştir.

Tablo 2.

Derslere Göre Etki Büyüklügü Farkları

\begin{tabular}{|c|c|c|c|c|c|c|c|}
\hline \multirow{2}{*}{$\begin{array}{l}\text { Değişken } \\
\text { Ders }\end{array}$} & \multirow{2}{*}{$\begin{array}{c}\text { Gruplar arası } \\
\text { Homojenlik } \\
\text { Değeri }\left(\mathbf{Q}_{\mathbf{B}}\right)\end{array}$} & \multirow{2}{*}{$\frac{\mathbf{p}}{0,803}$} & \multirow[t]{2}{*}{$\mathbf{n}$} & \multirow[t]{2}{*}{ ES } & \multicolumn{2}{|c|}{ ES (\%95 Cl) } & \multirow[t]{2}{*}{$\begin{array}{l}\text { Standart } \\
\text { Hata (SE) }\end{array}$} \\
\hline & & & & & Alt & Üst & \\
\hline Bilgisayar & & & 1 & 0,327 & $-0,943$ & 1,597 & 0,648 \\
\hline Fen & & & 8 & 1,013 & 0,563 & 1,462 & 0,229 \\
\hline H. Bilgisi & & & 2 & 1,117 & 0,181 & 2,053 & 0,478 \\
\hline İngilizce & & & 1 & 0,940 & $-0,284$ & 2,165 & 0,625 \\
\hline Matematik & & & 1 & 0,723 & $-0,564$ & 2,009 & 0,656 \\
\hline Sosyal & & & 3 & 1,475 & 0,645 & 2,306 & 0,424 \\
\hline Türkçe & & & 3 & 0,740 & $-0,002$ & 1,481 & 0,378 \\
\hline
\end{tabular}

$\chi^{2}$ tablosundan \%95 anlamlılık düzeyinde altı serbestlik derecesi ile kritik değer 12,592 olarak bulunmuştur. Derslere göre oluşturulan grupların arasındaki homojenlik değeri $\left(\mathrm{Q}_{B}\right)$ 3,046 olarak bulunmuştur. Gruplar arası homojenlik değerinin, kritik değerden daha küçük olmasından dolayı derslere göre oluşturulmuş gruplar arasında anlamlı bir fark bulunmamıştır $\left(Q_{B}=3,046, p>.05\right)$. 
Çalışmaların Sınıfların Düzeyleri ile ilgili Probleme Ait Bulgular

Etki büyüklüklerinin, sınıfların düzeyine göre farklılaşıp farklılaşmadığına ilişkin bulgular Tablo 3'te verilmiştir. Tablo 3.

Sınıf Düzeyine Göre Etki Büyüklüğü Farkları

\begin{tabular}{|c|c|c|c|c|c|c|c|}
\hline \multirow{2}{*}{$\begin{array}{c}\text { Değişken } \\
\text { Sınıf Düzeyi }\end{array}$} & \multirow{2}{*}{$\begin{array}{c}\text { Gruplar arası } \\
\text { Homojenlik } \\
\text { Değeri }\left(\mathbf{Q}_{\mathbf{B}}\right)\end{array}$} & \multirow{2}{*}{$\frac{\mathbf{p}}{0,766}$} & \multirow[t]{2}{*}{$\mathbf{n}$} & \multirow[t]{2}{*}{ ES } & \multicolumn{2}{|c|}{ ES (\%95 Cl) } & \multirow[t]{2}{*}{$\begin{array}{l}\text { Standart } \\
\text { Hata (SE) }\end{array}$} \\
\hline & & & & & Alt & Üst & \\
\hline 1.sınıf & & & 2 & 0,923 & 0,073 & 1,772 & 0,433 \\
\hline 2.sınıf & & & 1 & 1,434 & 0,139 & 2,729 & 0,661 \\
\hline 3. sinıf & & & 1 & 0,362 & $-0,860$ & 1,585 & 0,624 \\
\hline 4.sınıf & & & 4 & 0,841 & 0,229 & 1,452 & 0,312 \\
\hline 5.sınıf & & & 11 & 1,057 & 0,688 & 1,426 & 0,188 \\
\hline
\end{tabular}

$\chi^{2}$ tablosundan \%95 anlamlılık düzeyinde dört serbestlik derecesi ile kritik değer 9.488 olarak bulunmuştur. Sınıflara göre oluşturulan grupların arasındaki homojenlik değeri $\left(\mathrm{Q}_{B}\right)$ 1,838 olarak bulunmuştur. Gruplar arası homojenlik değerinin, kritik değerden daha küçük olmasından dolayı sınıflara göre oluşturulmuş gruplar arasında anlamlı bir fark bulunmamıştır $\left(Q_{B}=1,838, p>.05\right)$.

Çalışmaların Türü Ile Illgili Probleme Ait Bulgular

Etki büyüklüklerinin, çalışmaların türüne göre farklılaşıp farklılaşmadığına ilişkin bulgular Tablo 4'te verilmiştir. Tablo 4.

Çalışma Türüne Göre Etki Büyüklüğü Farkları

\begin{tabular}{|c|c|c|c|c|c|c|c|}
\hline \multirow{2}{*}{$\begin{array}{l}\text { Değişken } \\
\text { Çalışma Türü }\end{array}$} & \multirow{2}{*}{$\begin{array}{c}\text { Gruplar arası } \\
\text { Homojenlik } \\
\text { Değeri }\left(\mathbf{Q}_{\mathbf{B}}\right)\end{array}$} & \multirow{2}{*}{$\begin{array}{c}\mathbf{p} \\
0,583\end{array}$} & \multirow[t]{2}{*}{$\mathbf{n}$} & \multirow[t]{2}{*}{ ES } & \multicolumn{2}{|c|}{ ES (\%95 Cl) } & \multirow[t]{2}{*}{$\begin{array}{l}\text { Standart } \\
\text { Hata (SE) }\end{array}$} \\
\hline & & & & & Alt & Üst & \\
\hline Doktora & & & 3 & 1,257 & 0,624 & 1,890 & 0,323 \\
\hline Yüksek & & & 13 & 0,944 & 0,620 & 1,268 & 0,165 \\
\hline \multicolumn{8}{|l|}{ Lisans } \\
\hline Makale & & & 3 & 0,801 & 0,155 & 1,146 & 0,330 \\
\hline
\end{tabular}

$\chi^{2}$ tablosundan \%95 anlamlılık düzeyinde iki serbestlik derecesi ile kritik değer 5.991 olarak bulunmuştur. Yayın türlerine göre oluşturulan grupların arasındaki homojenlik değeri $\left(Q_{B}\right)$ 1,078 olarak bulunmuştur. Gruplar arası homojenlik değerinin, kritik değerden daha küçük olmasından dolayı yayın türlerine göre oluşturulmuş gruplar arasında anlamlı bir fark bulunmamıştır $\left(Q_{B}=1,078, p>.05\right)$.

Çalışmaların Süresi Ille Ilgili Probleme Ait Bulgular

Etki büyüklüklerinin, çalışmaların süresine göre farklılaşıp farklılaşmadığına ilişkin bulgular Tablo $5^{\prime}$ te verilmiştir.

Tablo 5.

Çalışma Süresine Göre Etki Büyüklüğü Farkları

\begin{tabular}{lccccccc}
\hline Değişken & $\begin{array}{c}\text { Gruplar } \\
\text { arası } \\
\text { Homojenlik }\end{array}$ & $\mathbf{p}$ & $\mathbf{n}$ & ES & ES (\%95 CI) & $\begin{array}{c}\text { Standart Hata } \\
\text { (SE) }\end{array}$ \\
\hline $\begin{array}{l}\text { Uygulama } \\
\text { Süresi }\end{array}$ & 1,932 & 0,166 & & & Alt & Üst & \\
\hline $\mathbf{0} \leq \mathbf{h} \leq \mathbf{1 9}$ & & & 8 & 0,762 & 0,366 & 1,158 & 0,202 \\
$\mathbf{2 0} \leq \mathbf{h}$ & & 11 & 1,133 & 0,789 & 1,478 & 0,176 \\
\hline
\end{tabular}

$\chi^{2}$ tablosundan \%95 anlamlılık düzeyinde bir serbestlik derecesi ile kritik değer 3.841 olarak bulunmuştur. Uygulama sürelerine göre oluşturulan grupların arasındaki homojenlik değeri $\left(Q_{B}\right)$ 1,932 olarak bulunmuştur. Gruplar arası homojenlik değerinin, kritik değerden daha küçük olmasından dolayı uygulama sürelerine göre oluşturulmuş gruplar arasında anlamlı bir fark bulunmamıştır $\left(Q_{B}=1,932, p>.05\right)$. 
Örneklem Büyüklügü Ile Illgili Probleme Ait Bulgular

Etki büyüklüklerinin, çalışmalardaki örneklem büyüklüğüne göre farklılaşıp farklılaşmadığına ilişkin bulgular Tablo 6'da verilmiştir.

Tablo 6.

Örneklem Büyüklüğüne Göre Etki Büyüklüğü Farkları

\begin{tabular}{lccccccc}
\hline Değişken & $\begin{array}{c}\text { Gruplar arası } \\
\text { Homojenlik } \\
\text { Değeri }\left(\mathbf{Q}_{\mathbf{B}}\right)\end{array}$ & $\mathbf{p}$ & $\mathbf{n}$ & ES & ES (\%95 Cl) & $\begin{array}{c}\text { Standart Hata } \\
\text { (SE) }\end{array}$ \\
\hline $\begin{array}{l}\text { Örneklem } \\
\text { büyüklüğü }\end{array}$ & 0,402 & 0,526 & & & Alt & Üst & \\
\hline $\mathbf{1} \leq \mathbf{N} \leq \mathbf{2 9}$ & & & 6 & 1,202 & 0,370 & 2,034 & 0,424 \\
$\mathbf{3 0} \leq \mathbf{N}$ & & & 13 & 0,922 & 0,680 & 1,164 & 0,123 \\
\hline
\end{tabular}

$\chi^{2}$ tablosundan \%95 anlamlılık düzeyinde bir serbestlik derecesi ile kritik değer 3.841 olarak bulunmuştur. Örneklem büyüklüğüne göre oluşturulan grupların arasındaki homojenlik değeri $\left(Q_{B}\right)$ 0,402 olarak bulunmuştur. Gruplar arası homojenlik değerinin, kritik değerden daha küçük olmasından dolayı örneklem büyüklüğüne göre oluşturulmuş gruplar arasında anlamlı bir fark bulunmamıştır $\left(Q_{B}=0,402, p>.05\right)$.

\section{TARTIŞMA, SONUÇ VE ÖNERILER}

Araştırmanın temel problemi "Öğretim teknolojileri kullanımının, 1260 ilkokul öğrencilerinin akademik başarıları üzerindeki etkisi ne düzeydedir?" şeklindedir. Öğretim teknolojileri kullanımının ilkokul öğrencilerinin akademik başarılarına etkisine ilişkin toplam 19 çalışma birleştirilmiştir. Çalışmalarda deney grubunda bulunan toplam örneklem sayısı 668, kontrol grubunda bulunan toplam örneklem sayısı 665 olup toplam örneklem sayısı 1333 olarak bulunmuştur. Yani toplam 1333 örneklemi içeren deneysel çalışmalar meta-analiz yöntemiyle birleştirilerek tek bir çalışma haline getirilmiştir. Rastgele etkiler modeline göre çalışmaların genel etki büyüklüğü değeri $\mathrm{ES}=0,973$ (\%95 Cl, SE=0,132) ile Cohen ve arkadaşlarının (2007) etki büyüklüğü sınıflandırmasına göre orta düzeyde ancak güçlü düzeye yakın bir etkidir. Öğretim teknolojileri kullanımının, 1333 ilkokul öğrencisinin akademik başarılarına etkisini tespit etmek amacıyla yapılan metaanaliz çalışması sonucunda, öğretim teknolojileri kullanımının geleneksel öğrenme yöntemlerine göre ilkokul öğrencilerinin akademik başarılarına daha etkili olduğu belirlenmiştir. 19 çalışmanın tamamı pozitif yönlü çıkmıştır. Meta-analiz yöntemi ile birleştirilen 19 çalışmanın etki büyüklüğünü, 0,01 etki büyüklüğü değerine düşürmek için etki büyüklüğü değeri sıfır olan en az 1790 çalışma gerekmektedir. Orwin Güvenli N yöntemiyle belirlenen çalışma sayılarının fazlalığına bakarak elde edilen analiz sonuçlarının geçerli ve yayın yanlılığının düşük olduğu söylenebilir.

Araştırmanın ikinci sorusu "Öğretim teknolojileri ile ilgili yayınların etki büyüklükleri arasında, ilkokul öğrencilerinin farklı derslerdeki akademik başarılarında anlamlı bir farklıık var mıdır?" şeklindedir. Bilgisayar, Ingilizce ve matematik alanlarında 1, Fen Bilgisi alanında 8, Hayat Bilgisi alanında 2, Sosyal Bilgiler ve Türkçe alanlarında üçer çalışma bulunmaktadır. Derslerin ortalama etki büyüklükleri karşılaştırıldığında en yüksek etki büyüklüğü değerinin sosyal ( $E S=1,475)$, Hayat Bilgisi $(E S=1,117)$, Fen $(E S=1,013)$ alanında olduğu sonucuna ulaşılmıştır. Bu etki büyüklüklerine bakıldığında güçlü etki büyüklüğüne sahip oldukları ifade edilebilir. Bunun yanında Matematik $(E S=0,723)$, Türkçe alanında $(E S=0,740)$ bilgisayar alanında $(E S=0,327)$ olduğu belirlenmiştir. Bu etki büyüklüklerinin küçük ve orta düzeyde etki büyüklüğüne sahiptir. Gruplar arası homojenlik değerine $\left(Q_{B}=3,046\right)$ bakıldığında bu değerin $\chi^{2}$ tablosunda \%95 anlamlılık düzeyinde altı serbestlik derecesi ile kritik değerden $(12,592)$ küçük olduğu görülmüştür. Bu nedenle derslere göre oluşturulmuş gruplar arasında anlamlı bir farklılık bulunmamıştır $\left(Q_{B}=3,046, p<.05\right)$. Buna göre; derslerin, öğretim teknolojileri kullanımının etki büyüklüğünü anlamlı bir fark olacak şekilde değiştirmediği görülmektedir.

Araştırmanın üçüncü sorusu "Öğretim teknolojileri ile ilgili yayınların etki büyüklükleri arasında, ilkokul öğrencilerinin sınıf düzeylerine göre akademik başarılarında anlamlı bir farklıık var mıdır?" şeklindedir. Sınıf düzeyinde çalışmalara bakıldığında birinci sınıf düzeyinde 2, ikinci sınıf düzeyinde 1, üçüncü sınıf düzeyinde 1, dördüncü sınıf düzeyinde 4, beşinci sınıf düzeyinde 11 çalışma bulunmaktadır. Sınıfların ortalama etki büyüklüklerine bakıldığında en yüksek etki büyüklüğü ortalamasına ikinci $(E S=1,434)$ ve beşinci sınıf 
(ES=1,057) düzeylerinin sahip olduğu tespit edilmiştir. Bu etki büyüklüğü ortalamalarının güçlü olduğu ifade edilebilir. Bunun yanında üçüncü sınıf düzeyinin $(E S=0,362)$ etki büyüklüğü ortalamasının ise küçük olduğu söylenebilir. Sınıf düzeyinde $\chi^{2}$ tablosundan \%95 anlamlılık düzeyinde dört serbestlik derecesi ile kritik değer 9.488 olarak bulunmuştur. Sınıflara göre oluşturulan grupların arasındaki homojenlik değeri $\left(\mathrm{Q}_{B}\right)$ 1,838 olarak bulunmuştur. Gruplar arası homojenlik değerinin, kritik değerden daha küçük olmasından dolayı sınıf düzeyine göre oluşturulmuş gruplar arasında anlamlı bir fark bulunmamıştır $\left(Q_{B}=1,838, p<.05\right)$.

Araştırmanın dördüncü sorusu "Öğretim teknolojileri ile ilgili yayınların etki büyüklükleri arasında, ilkokul öğrencilerinin akademik başarılarında yayın türlerine göre anlamlı bir farklılık var mıdır?" şeklindedir. Çalışma türüne göre bulgular incelendiğinde 13 yüksek lisans tezi, üç adet doktora tezi ve üç adet makalenin bulunduğu görülmektedir. Çalışma türlerinin ortalama etki büyüklükleri incelendiğinde en yüksek ortalamaya doktora tezi $(E S=1,257)$ çalışmaları sahiptir ve bu çalışmaları etki büyüklüğü ortalamaları güçlüdür. Yüksek lisans tezi $(E S=0,944)$ ve makale $(E S=0,801)$ çalışmalarının etki büyüklüğü ortalamaları orta düzeydedir. $\chi^{2}$ tablosundan \%95 anlamlılık düzeyinde iki serbestlik derecesi ile kritik değer 5.991 olarak bulunmuştur. Yayın türlerine göre oluşturulan grupların arasındaki homojenlik değeri $\left(\mathrm{Q}_{B}\right)$ 1,078 olarak bulunmuştur. Gruplar arası homojenlik değerinin, kritik değerden daha küçük olmasından dolayı yayın türlerine göre oluşturulmuş gruplar arasında anlamlı bir fark bulunmamıştır $\left(Q_{B}=1,078, p<.05\right)$.

Araştırmanın beşinci sorusu "Öğretim teknolojileri ile ilgili yayınların etki büyüklükleri arasında, çalışmalardaki uygulama süresine (1-19 saat, 20 ve üstü saat) göre ilkokul öğrencilerinin akademik başarılarında anlamlı bir farklııık var mıdır?" şeklindedir. Çalışma süresine göre bulgular incelendiğinde alt boyutta yer alan (1-19 saat) çalışmaların 8, üst boyutta yer alan çalışmaların (20 ve üzeri) 11 adet olduğu görülmektedir. Bu çalışmaların etki büyüklüğü ortalamalarına bakıldığında üst boyutunda yer alan çalışmaların etki büyüklüğünün $(E S=1,133)$ güçlü düzeyde bir ortalamaya, alt boyutunda yer alan çalışmaların $(E S=0,762)$ orta düzeyde etki büyüklüğü ortalamasına sahip oldukları ifade edilebilir. Bu çalışmalar için $\chi^{2}$ tablosundan \%95 anlamlılık düzeyinde bir serbestlik derecesi ile kritik değer 3.841 olarak bulunmuştur. Uygulama sürelerine göre oluşturulan grupların arasındaki homojenlik değeri $\left(\mathrm{Q}_{B}\right)$ 1,932 olarak bulunmuştur. Gruplar arası homojenlik değerinin, kritik değerden daha küçük olmasından dolayı uygulama sürelerine göre oluşturulmuş gruplar arasında anlamlı bir fark bulunmamıştır $\left(\mathrm{Q}_{B}=1,932, \mathrm{p}<.05\right)$.

Araştırmanın altıncı sorusu "Öğretim teknolojileri ile ilgili yayınların etki büyüklükleri arasında, çalışmalardaki örneklem büyüklüğüne (1-29 kişi, 30 ve üstü kişi) göre ilkokul öğrencilerinin akademik başarılarında anlamlı bir farklılık var mıdır?" şeklindedir. Örneklem büyüklüğüne göre bulgular incelendiğinde alt boyutta yer alan (1-29 kişi) çalışmaların 6, üst boyutta yer alan çalışmaların (30 ve üstü kişi) 13 adet olduğu görülmektedir. Bu çalışmaların etki büyüklüğü ortalamalarına bakıldığında alt boyutunda yer alan çalışmaların etki büyüklüğünün $(E S=1,202)$ güçlü düzeyde bir ortalamaya, üst boyutunda yer alan çalışmaların $(E S=0,922)$ orta düzeyde etki büyüklüğü ortalamasına sahip oldukları ifade edilebilir. Bu çalışmalar için $\chi^{2}$ tablosundan \%95 anlamlılık düzeyinde bir serbestlik derecesi ile kritik değer 3.841 olarak bulunmuştur. Örneklem büyüklüğüne göre oluşturulan grupların arasındaki homojenlik değeri $\left(\mathrm{Q}_{B}\right)$ 0,9402 olarak bulunmuştur. Gruplar arası homojenlik değerinin, kritik değerden daha küçük olmasından dolayı örneklem büyüklüğüne göre oluşturulmuş gruplar arasında anlamlı bir fark bulunmamıştır $\left(Q_{B}=0,402, p<.05\right)$.

Araştırma sonuçlarına göre; öğretim teknolojilerini, öğrencilerin akademik başarılarını arttırmak için, ders olarak sosyal, hayat bilgisi ve fen derslerinde, sınıf düzeyi olarak ikinci ve beşinci sınıflarda, yayın türünde doktora tezlerinde, uygulama süresinde "20 ve üstü" ders saatinde ve örneklem büyüklüğünde "1-29 kişi" aralığında kullanmak daha fazla etkili olmaktadır. Bunun yanında gelişim dönemine uygun materyallerin araştırma yaparken titizlikle seçilmesi gerekir (Alkan, 2011; Ekici, 2014; Merrill, 1994; Smith ve Ragan, 2004), bu ihmal edilmişse materyallerin etkililiği ile ilgili bazı sorunların yaşanabilmesi mümkündür. Ayrıca Erktin ve Gülseçen (2001), öğretmenlerin üçte birinin teknolojik materyal kullanımına karşı direnç gösterebildikleri yönünde görüş belirtmiştir. Bu direncin aşılması durumunda öğrenme sürecinde daha etkili materyaller kullanımları sağlanabilir.

Araştırma sonuçlarına göre; öğretim teknolojilerini, öğrencilerin akademik başarılarını arttırmak için, ders olarak bilgisayar, matematik ve Türkçe derslerinde, sınıf düzeyi olarak üçüncü ve dördüncü sınıflarda, yayın türünde makalelerde, uygulama süresinde "1 ile 19 arası" ders saatinde ve örneklem büyüklügüunde "30 ve üstü kişi" aralığında kullanmak daha az etkili olmaktadır. 
Araştırmada elde edilen sonuçlara dayalı olarak uygulayıcılara, program geliştiricilere ve de araştırmacılara yönelik şu önerilerde bulunulabilir.

Uygulayıcılara yönelik öneriler;

- $\quad$ Illkokul öğretmenleri etkili bir öğrenme için öğretim teknolojilerini kullanabilirler.

- $\quad$ Öğretim materyalleri özellikle sosyal ve fen alanlarıyla ilgili derslerde kullanılabilir.

- Öğretim teknolojileri, ilkokul öğrencilerinin akademik başarılarını arttırmak için özellikle ikinci ve beşinci sınıf düzeylerinde kullanılabilir.

- $\quad$ Araştırma sonucunda "20 ve üstü" ders saatinde etki büyüklüğü yüksek çıktığından öğretim teknolojilerinin öğrencinin konuları anlayıp, kavramasını sağlayacak kadar sürede kullanılması gerekmektedir.

Program geliştiricilere yönelik öneriler;

- Öğretim programlarında öğretim teknolojilerinin, ilkokul öğrencilerinin akademik başarılarını arttıran derslerde daha fazla yer verilmesi ve kullandırılması sağlanabilir.

- Özellikle ilkokul 2. ve 5. Sınıf öğretim programlarında öğretim teknolojilerine yer vermek öğrencilerin akademik başarısını arttırabilir.

- Öğretim programlarında ve ders kitaplarında yer alan öğretim teknolojileri ile ilgili etkinlikler planlanırken sürenin öğrencileri daha verimli kılacak şekilde düzenlenmesi işlevselliği arttıracaktır.

- Öğretim teknolojilerinin, sınıf mevcudunun az olması durumunda daha etkili olduğu tespit edildiğinden, mevcudu yüksek sınıfların mevcutlarının azaltılmaya çalışılması faydalı olabilir.

Araştırmacılara yönelik öneriler;

- Literatürde çalışma sayısı az olan değişkenler için özellikle çalışma yapılırsa meta-analiz sonuçlarının güvenirliği artacak ve öğretim teknolojileri ile ilgili daha sağlıkı veriler elde edilebilecektir.

- Doktora tezlerindeki etki büyüklüklerinin, yüksek lisans tezlerinin ve makalelerin etki büyüklüklerinden, istatistiksel olarak anlamlı fark olmasa da, daha yüksek olmasının nedenleri araştırılabilir.

- 4+4+4 eğitim sistemindeki haliyle ilkokul düzeyinde yeni ve kapsamlı çalışmalar yapılabilir.

\section{KAYNAKÇA/REFERENCES}

Akçayır, M. (2011). Akıllı tahta kullanılarak işlenen matematik dersinin sınıf öğretmenliği birinci sınıf öğrencilerinin başarı, tutum ve motivasyonlarına etkisi. Yayınlanmamış yüksek lisans tezi. Ankara: Gazi Üniversitesi Eğitim Bilimleri Enstitüsü.

Akın, M. (2007). Bilgisayar ve internet teknolojilerinden yararlanmanın uygulama alan bilgisi oluşturma yönünde etkisi (Erzincan Eğitim Fakültesi örneği). Erzincan Eğitim Fakültesi Dergisi, 9(2), 49-70.

Akkaya, A. (2011) Karikatürlerle dil bilgisi öğretimi. Yayımlanmamış doktora tezi. Konya: Selçuk Üniversitesi Eğitim Bilimleri Enstitüsü.

Alkan, C. (2011). Eğitim teknolojisi. Ankara: Anı.

Aktaş Çam, B. (2014). Bilgi ve İletişim Teknolojileri Tabanlı Öğretim Materyalleri ve Uygulamalar. Ekici, G. (Ed.) Öğretim Teknolojileri ve Materyal Tasarımı içinde (s.185-211). Edirne: Paradigma Akademik.

Ayaydın, Y. (2014). Sosyal bilgiler öğretiminde öğretim teknolojilerinin kullanımına ilişkin hizmet-içi ve hizmetöncesi sosyal bilgiler öğretmenlerinin görüşlerinin incelenmesi. Yayınlanmamış yüksek lisans tezi. İstanbul: Marmara Üniversitesi Eğitim Bilimleri Enstitüsü.

Ayaz, M. F. (2015). Sorularla meta-analiz. Diyarbakır: Dicle Üniversitesi.

Bayturan, S. (2011). Ortaöğretim matematik eğitiminde bilgisayar destekli öğretimin, öğrencilerin başarıları, tutumları ve bilgisayar öz-yeterlilik algıları üzerindeki etkisi. Yayınlanmamış doktora tezi. İzmir: Dokuz Eylül Üniversitesi Eğitim Bilimleri Enstitüsü.

Birişçi, S. ve Metin, M. (2009). Fen konularına yönelik web sayfası hazırlama öğretmen adaylarının bilgisayar teknolojisini kullanabilme becerilerini nasıl etkiler? Necatibey Eğitim Fakültesi Elektronik Fen ve Matematik Eğitimi Dergisi, 3(2), 74-93.

Borenstein, B., Hedges, L.V., Higgins, J.P.T. ve Rothstein, H.R. (2013). Meta-analize giriş. (S. Dinçer, Çev.) Ankara: Anı.

Borenstein, M., Hedges, L.V., Higgins, J.P.T. ve Rothstein, H.R. (2009). Introduction to meta-analysis . United Kingdom: John Wiley and Sons.

Cohen, J. (1988). Statistical power analysis for the behavioral sciences. New York: Academic Press. 
Cohen, L., Manion, L. ve Morrison, K. (2007). Research methods in education (6th Edition). New York: Routledge.

DeCoster, J. (2004). Meta-analysis notes. Alabama: University of Alabama Department of Psychology.

Demirel, Ö. ve Altun, E. (2012). Öğretim teknolojileri ve materyal tasarımı. Ankara: PegemA.

Ekici, G. (2014). Öğretim teknolojileri ve materyal tasarımı. İstanbul: Paradigma Akademi

Ergene, T. (1999). Effectiveness of test anxiety reduction programs: A meta-analysis review. Doktora tezi. Ohio: Ohio Üniversitesi.

Erktin, E. ve Gülseçen, S. (2001). Eğitimde bilişim teknolojilerinin kullanımını etkileyen psikolojik etmenler. Eğitim ve Bilim, 26(121), 7-11.

Fer, S. (2011). Öğretim tasarımı (2. Baskı). Ankara: Anı.

Gagne, R. M., Briggs, L. J. ve Wager, W. W. (1992). Principles of instructional design. Philadelphia: Harcourt Brace Jovanovich Colege.

Gürol, M., Donmuş, V. ve Arslan, M. (2012). İlköğretim kademesinde görev yapan sınıf öğretmenlerinin fatih projesi ile ilgili görüşleri. Eğitim Teknolojileri Araştırmaları Dergisi, 3(3).

Halis, İ. (2001). Öğretim teknolojileri ve materyal geliştirme. Konya: Mikro.

Hedges, L.V. ve Olkin, I. (1985). Statistical methods for meta-analysis. New York: Academic Press.

Huffcutt, A. (2002). Research perspectives on meta analysis. S. G. Rogelberg (Ed.), Handbook of research methods in industrial and organizational psychology içinde (s. 198-215). Oxford: Blackwell.

Hunter, J.E. ve Schmidt, F.L. (1990). Methods of meta-analysis: Correcting error and bias in research findings. London: Sage.

İlyasoğlu, U. (2012). Genel fizik-I dersinde "doğru akım devreleri" konusunun öğretiminde bilgisayar destekli ögrretimin fen ve teknoloji öğretmen adaylarının başarısına etkisi. Yayınlanmamış yüksek lisans tezi. Kastamonu: Kastamonu Üniversitesi Fen Bilimleri Enstitüsü.

İnce, S. (2011). ilköğretim 5. Sınıfta rasyonel sayılar konusundaki yanılgılar ve bu yanılgıların ortadan kaldırılması için öneriler. Yayınlanmamış yüksek lisans tezi. İzmir: Ege Üniversitesi Sosyal Bilimler Enstitüsü.

İşman, A. (2002). Sakarya ili öğretmenlerinin eğitim teknolojileri yönündeki yeterlilikleri. The Turkish Online Journal of Educational Technology, 1(1), 72-92.

Keser, H., Çakır, H. (2009). Çoklu zeka kuramına göre hazırlanmış olan bilgisayar destekli trafik eğitim'ine ilişkin öğrenci görüşleri. Kastamonu Eğitim Dergisi, 17(3), 835-848.

Lipsey, M. ve Wilson, D. (2001). Practical meta-analysis. Beverly Hills, CA: Sage.

Mayer, R. E. (2003). The promise of multimedia learning: Using the same instructional design methods across different media. Learning and Instruction, 13, 125-139.

Merrill, M. D. (1994). Instructional Design Theory. New Jersey: Educational Technology.

Miles, M. B. ve Huberman, A. M. (2002). The qualitative researcher's companion. California: Sage.

Ocak, M. A. (2011). Öğretim tasarımı. Ankara: Anı.

Özdemir, A. (2006). Bilgi yönetimi ve kurumsal yaklaşım. Yüksek lisans tezi. İstanbul: Marmara Üniversitesi Türkiyat Araştırmaları Enstitüsü.

Öztürk, M. (2014). 8. Sınıf kuvvet ve hareket ünitesine yönelik bilgisayar destekli öğretim uygulamalarının etkililiğinin araştırılması. Yayınlanmamış yüksek lisans tezi. Trabzon: Karadeniz Teknik Üniversitesi Eğitim Bilimleri Enstitüsü.

Rosenthal, R. (1991). Meta-analytic procedures for social research. Beverly Hills, CA: Sage Publications

Sağlıker, Ş. (2009). Yapılandırmacı öğrenme kuramına dayalı olarak kütle çekim kanunu konusunda hazırlanan ders yazılımının öğrencilerin akademik başarısına etkisi. Yayınlanmamış yüksek lisans tezi. Adana: Çukurova Üniversitesi Sosyal Bilimler Enstitüsü.

Schulze, R. (2004). Meta-analysis a comparison of approaches. Göttingen: Hogrefe \& Huber.

Sever, R. (2011). Öğretim teknolojileri ve materyal tasarımı. Ankara: Anı.

Smith, P. L. ve Ragan, T. J. (2004). Instructional design. New York: John Wiley \& Sons.

Şenlen, E, M. (2015). Bilgisayar destekli öğretimin orta öğretim öğrencilerinin madde döngüleri ve enerji dönüşümleri ünitesindeki başarılarına etkisi. Yayınlanmamış yüksek lisans tezi. Ankara: Gazi Üniversitesi Eğitim Bilimleri Enstitüsü.

Şimşek, A. (2011). Öğretim tasarımı (2. Basım). Ankara: Nobel.

Tosun, N. (2006). Bilgisayar destekli ve bilgisayar temelli öğretim yöntemlerinin, öğrencilerin bilgisayar dersi başarısı ve bilgisayar kullanım tutumlarına etkisi: Trakya üniversitesi eğitim fakültesi örneği. Yayınlanmamış doktora tezi. Edirne: Trakya Üniversitesi Fen Bilimleri Enstitüsü.

Uşun, S. (2006). Uzaktan eğitim. Ankara: Nobel.

Ünal, M.( 2012). Bilgi çağında değişim ve liderlik. Marmara Üniversitesi i.i.B.F. Dergisi, 32(1). 297-310. 
Üstün, U. ve Eryılmaz, A. (2014). Etkili araştırma sentezleri yapabilmek için bir araştırma yöntemi: Meta-analiz. Eğitim ve Bilim, 1-32.

Wolf, F. M. (1988). Meta-analysis quantitative methods for research synthesis (Third edition). California: Sage. Yalpar, Yelken, T. (2012) Öğretim ilkeleri ve materyal tasarımı (11. Baskı). Ankara: Anı.

İletişim/Correspondence Dr. Mehmet Fatih Ayaz mf_ayaz@hotmail.com

Arş. Gör. Hanifi Şekerci hnfskrc@gmail.com

Prof. Dr. Behçet Oral oralbehcet@dicle.edu.tr 


\section{Ek-1. Meta-Analize Dâhil Edilen Çalışmalar}

Akamca Özyılmaz, G. (2008). Ilköğretimde analojiler, kavram karikatürleri ve tahmin-gözlem-açılama teknikleriyle desteklenmiş fen ve teknoloji eğitiminin öğrenme ürünlerine etkisi. Yayınlanmamış doktora tezi. İzmir: Dokuz Eylül Üniversitesi Eğitim Bilimleri Enstitüsü.

Atam, Ö. ve Tekdal M. (2007). Fen ve Teknoloji dersi ısı-sıcaklık konusunda hazırlanan simülasyon tabanlı bir yazılımın ilköğretim 5.sınıf öğrencilerin akademik başarılarına ve kalııılığa etkisi. Çanakkale: Çanakkale Onsekiz Mart Üniversitesi Eğitim Fakültesi Dergisi, 6(18), 635-651.

Baba, M. (2012). Ilköğretim öğrencilerine vatandaşlık bilinci kazandırmada kavram karikatürü kullanımının etkisi. Yayınlanmamış yüksek lisans tezi. Samsun: Ondokuz Mayıs Üniversitesi Eğitim Bilimleri Enstitüsü.

Babur, A. (2010). Bolu Gazipaşa ilköğretim okulu 5. Sınıf bilişim teknolojileri dersinde ağ günlüğü ortamında "yayıncllı̆a başlıyorum" ünitesinin işlenmesinin eleştirel düşünmeye, kalıcılığa ve akademik başarıya etkisi. Yayınlanmamış yüksek lisans tezi. Ankara: Gazi Üniversitesi Eğitim Bilimleri Enstitüsü.

Baysarı, E. (2007). Ilköğretim düzeyinde 5.Sınıf Fen ve Teknoloji dersi canlılar ve hayat ünitesi Öğretiminde kavram karikatürü kullanımının öğrenci başarısına, fen tutumuna ve kavram yanılgılarının giderilmesine olan etkisi. Yayınlanmamış yüksek lisans tezi. İzmir: Dokuz Eylül Üniversitesi Eğitim Bilimleri Enstitüsü.

Çamlı Çakır, H. ve Altun, E. (2011). Bilgisayar destekli zihin haritalama tekniğinin ilköğretim 5. Sınıf öğrencilerinin fen ve teknoloji dersindeki akademik başarılarına ve tutumlarına etkisi. Eğitim Teknolojileri Araştırmaları Dergisi, 2(4), 32-45..

Çalışır, F. (2011). Hayat bilgisi dersinde karikatürlerle öğretimin öğrenci başarısına etkisi. Yayınlanmamış yüksek lisans tezi. Eskişehir: Osmangazi Üniversitesi Eğitim Bilimleri Enstitüsü.

Erdağ, S. (2011). ilköğretim 5. Sınıf matematik dersinde kavram karikatürleri ile destekli matematik öğretiminin, ondalık kesirler konusundaki akademik başarıya ve kalıcılığa etkisi. Yayınlanmamış yüksek lisans tezi. İzmir: Dokuz Eylül Üniversitesi Eğitim Bilimleri Enstitüsü.

Işlak, O. (2011). Yapılandırmacı yaklaşım temelli, bilgisayar tabanlı, sosyal bilgiler öğretim materyalinin etkililiği. Yayınlanmamış yüksek lisans tezi. Burdur: Mehmet Akif Ersoy Üniversitesi Sosyal Bilimler Enstitüsü.

İzgi, Ü. (2012). Öğretmen adaylarının eğitiminde ve ilköğretim ı. Kademe fen eğitiminde kavram karikatürü kullanımının etkileri. Yayınlanmamış doktora tezi. Ankara: Hacettepe Üniversitesi Sosyal Bilimler Enstitüsü.

Kıy Can, S. (2009). İlköğretim 4. ve 5. sınıflarda sosyal bilgiler dersinde (araç-gereç) materyal kullanımının öğrenci başarısına etkisi (Kars ili örneği). Yayınlanmamış yüksek lisans tezi. Kars: Kafkas Üniversitesi Sosyal Bilimler Enstitüsü.

Orhan H., G. (2007). Bilgisayar destekli öğretimin ilkokuma yazma başarısına etkisi. Yayınlanmamış yüksek lisans tezi. İstanbul: Marmara Üniversitesi Eğitim Bilimleri Enstitüsü.

Özden, M. (2005). Fen bilgisi dersinde beyin temelli öğrenmenin akademik başarıya ve hatırlama düzeyine etkisi. Yayınlanmamış yüksek lisans tezi. Eskişehir: Anadolu Üniversitesi Eğitim Bilimleri Enstitüsü.

Pektaş, H. M., Çelik, H., Katrancı, M. ve Köse, S. (2009). 5. sınıflarda ses ve ışık ünitesinin öğretiminde bilgisayar destekli öğretimin öğrenci başarısına etkisi. Kastamonu Eğitim Dergisi, 17(2), 649-658.

Şen, M. (2013). Illköğretim birinci kademe ingilizce öğretiminde akıllı tahta kullanımının öğrenci başarısına etkileri. Yayınlanmamış yüksek lisans tezi. İstanbul: İstanbul Üniversitesi Eğitim Bilimleri Enstitüsü.

Şerifoğlu Hiçyılmaz, G. (2013). Sosyal bilgiler öğretiminde beyin temelli öğrenme yaklaşımına uygun ortam tasarımının öğrencilerin akademik başarılarına ve derse yönelik tutumlarına etkisi. Yayınlanmamış yüksek lisans tezi. Ankara: Gazi Üniversitesi Eğitim Bilimleri Enstitüsü.

Turan, K. (2012). 5. Sınıf öğrencilerinin basit elektrik devreleri konusundaki başarısına bilgisayar destekli öğretimin etkisi. Yayınlanmamış yüksek lisans tezi. İzmir: Ege Üniversitesi Sosyal Bilimler Enstitüsü.

Yıldız, S. (2007). ilkokuma yazma öğretiminde çoklu ortam uygulamalarının etkililiği. Yayınlanmamış doktora tezi. Bolu: Abant İzzet Baysal Üniversitesi Sosyal Bilimler Enstitüsü.

Zobar, Y. (2010). Bilgisayar destekli öğretimin ilköğretim üçüncü sınıf öğrencilerinin başarısı ve tutumuna etkisi. Yayınlanmamış yüksek lisans tezi. Sakarya: Sakarya Üniversitesi Sosyal Bilimler Enstitüsü. 


\section{Ek-2: Kodlama Formu}

1. Çalışmanın numarası:

2. Çalışmanın adı:

3. Çalışmanın yazarı/yazarları:

4. Çalışmanın yayımlandığı yıl:

5. Çalışmanın yayın türü:

6. Çalışmanın uygulama süresi:

7. Dersin adı:

8. Çalışmanın uygulandığı öğrenci grubunun öğrenim düzeyi:
( ) 1
( ) 2
( ) 3
( ) 4
( ) 5

9. Çalışmadaki toplam örneklem sayısı:

10. Deney ve kontrol grupları başarı testi tanımlayıc istatistikler;

\begin{tabular}{|l|l|l|l|l|l|l|}
\hline & \multicolumn{4}{|l|}{ Deney Grubu } & \multicolumn{3}{l|}{ Kontrol Grubu } \\
\hline & $\mathrm{N}$ & $\mathrm{X}$ & $\mathrm{S}$ & $\mathrm{N}$ & $\mathrm{X}$ & $\mathrm{S}$ \\
\hline Öntest & & & & & & \\
\hline Sontest & & & & & & \\
\hline
\end{tabular}

$\mathrm{N}$ :Örneklem hacmi,

X: Grubun ortalaması,

S: Grubun standart sapması

11. Çalışmanın etki büyüklüğü: 
